CÉSAR VALLEJO 
The publisher gratefully acknowledges the generous contribution to this book provided by the Ahmanson Foundation Humanities Endowment Fund of the University of California Press Foundation.

The publisher also gratefully acknowledges the generous contribution toward the publication of this book provided by the Director's Circle of the University of California Press Foundation, whose members are:

ROBERT \& ALICE BRIDGES FOUNDATION

EARL \& JUNE CHEIT

LLOYD COTSEN

SONIA H. EVERS

ORVILLE \& ELLINA GOLUB

ANN GIVEN HARMSEN \& BILL HARMSEN

DANIEL HEARTZ

LEO \& FLORENCE HELZEL

MRS. CHARLES HENRI HINE

PATRICK KING

RUTH A. SOLIE 


\section{THE COMPLETE POETRY}

\section{A BILINGUAL EDITION \\ CÉSAR VALLEJO}

EDITED AND TRANSLATED BY

CLAYTON ESHLEMAN

WITH A FOREWORD BY

MARIO VARGAS LLOSA

AN INTRODUCTION BY

EFRAÍN KRISTAL

AND A CHRONOLOGY BY

STEPHEN M. HART

무

UNIVERSITY OF CALIFORNIA PRESS

BERKELEY LOS ANGELES LONDON 
University of California Press, one of the most distinguished university presses in the United States, enriches lives around the world by advancing scholarship in the humanities, social sciences, and natural sciences. Its activities are supported by the UC Press Foundation and by philanthropic contributions from individuals and institutions. For more information, visit www.ucpress.edu.

University of California Press

Berkeley and Los Angeles, California

University of California Press, Ltd.

London, England

(C) 2007 by The Regents of the University of California

Library of Congress Cataloging-in-Publication Data

Vallejo, César, I892-1938.

[Poems. English \& Spanish]

The complete poetry : a bilingual edition / César Vallejo ; edited and translated by Clayton Eshleman ; with a foreword by Mario Vargas Llosa ; an introduction by Efraín Kristal ; and a chronology by Stephen M. Hart.

p. $\quad \mathrm{cm}$.

Includes bibliographical references and index.

Contents: Los heraldos negros $=$ The black heralds - Trilce - Poemas humanos $=$ Human Poems España, aparta de mí este calíz = Spain, take this cup from me.

ISBN-I3: 978-0-520-24552-5 (cloth : alk. paper)

ISBN-IO: 0-520-24552-O (cloth : alk. paper).

I. Vallejo, César, I892-I938 - Translations into English. I. Eshleman, Clayton. II. Title.

PQ8497.V35A2 2007

$86 \mathrm{I}^{\prime} .62-\mathrm{dc} 22$ 2006045620

Manufactured in the United States of America
$\begin{array}{llllllllll}\text { I6 } & \text { I5 } & \text { I4 } & \text { I3 } & \text { I2 } & \text { II } & \text { I0 } & 09 & 08 & 07\end{array}$

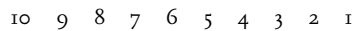

This book is printed on New Leaf EcoBook 50 , a 100\% recycled fiber of which $50 \%$ is de-inked postconsumer waste, processed chlorine-free. EcoBook 50 is acid-free and meets the minimum requirements of ANSI/ASTM D5634-OI (Permanence of Paper). 
In memory of José Rubia Barcia (1914-1997),

dear friend and early collaborator 


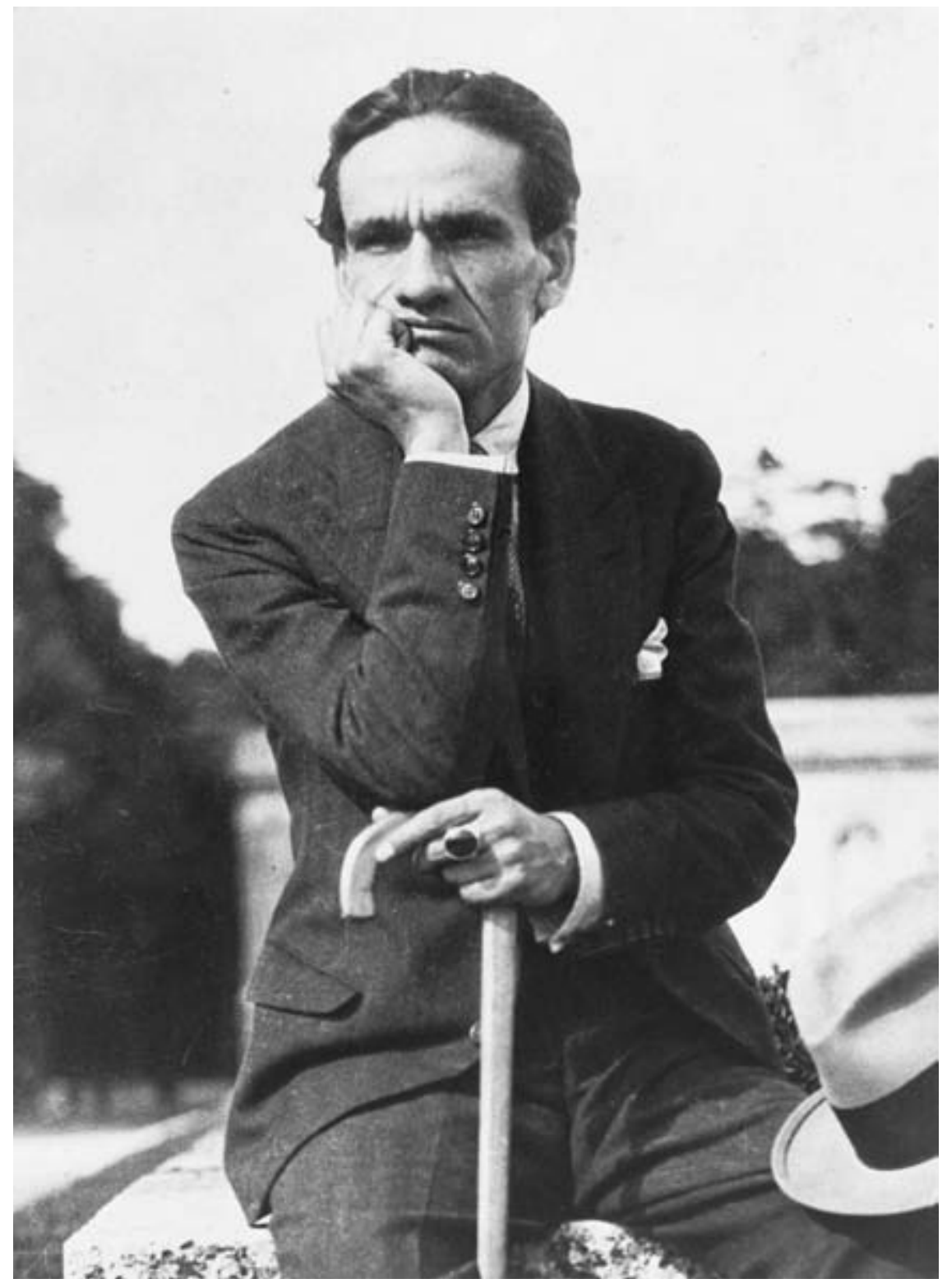

CÉSAR VALLEJO. Photograph taken by Juan Domingo Córdoba Vargas in Versailles, 1929. 